\title{
CHEMICAL STUDIES ON SOME MEDICAL HERBS AGAINST GAMMA RADIATION INDUCED BIOCHEMICAL DISTURBANCE IN THE LIVER AND CARDIAC FUNCTIONS OF RATS
}

\author{
M.A. Hammam ${ }^{(1)}$, M.I.A. Heibashy ${ }^{(2)}$, F.M. El-Shouny ${ }^{(1)}$ and F.A. Shahin ${ }^{(2)}$ \\ (1) Biochemistry Department. Faculty of Agriculture. Monofia University. \\ ${ }^{(2)}$ Nuclear Research Centre, Atomic Energy Authority.
}

Received: Apr. 11, 2017

Accepted: May 7, 2017

\begin{abstract}
The objective of this study was to evaluate the ability of ginseng, green tea or/and cinnamon to improve the disturbances occur in liver, heart, lipid and thyroid profiles as well as antioxidant and lipid peroxidation status in rats as a result of exposure to $\gamma$-irradiation. The obtained results revealed a significant $(p<0.05)$ increase in serum alanine transferase $(A L T)$, aspartate transferase (AST), lactate dehydrogenase ( $L D H)$ and creatine kinase (CK) activities as well as elevations in the levels of total cholesterol, triglycerides, high density cholesterol (HDL-Ch) and low density cholesterol (LDL-Ch) in irradiated rats than those in control ones. On the other hand, the concentrations of serum total protein, albumin and free triiodothyronine $\left(F T_{3}\right)$ were remarkable decreased in rats as a result of exposure to $\gamma$-irradiation. Moreover, as a result of exposure to $y$-radiation, the mean value of GSH content and Gpx activity were remarkable decreased in both the liver tissues and in the cardiac tissues of the rats. On the contrary, the exposure to $y$-radiation caused a significant $(P<0.001)$ increment in thiobarbituric acid reactive substance (TBARS) level in both liver and heart tissues of rats. When $y$-irradiated rats groups were treated with ginseng, green tea or cinnamon, considerable amelioration effects in all previous studied parameters were pronounced dependent on time of treatment ( 15 \& 30 days). The maximum correction was occurred in all studied parameters in irradiated-rats treated with mixture of ginseng, green tea and cinnamon dependent on the time of treatment (15 and 30 days). So, this study can practically help to encourage the clinical use of this mixture as a treatment for exposure to $y$-radiation. These mechanisms were discussed according to available recent researches.
\end{abstract}

Key words: Gamma irradiation, Taurine, Ginseng, Green tea, Cinnamon, Rat

\section{INTRODUCTION}

lonizing radiation produces harmful effects on the organisms and due to wide spread use of radiation in diagnosis therapy, industry; so many pharmacological interventions could be most potent strategy to protect or amelioration the deleterious effect of ionizing radiation (Heibashy \& Sharoud, 2008). Ionizing radiations induce hepatotoxicity associated with significant disturbance in the physiological and metabolic processes, as well as, disorders in serum liver function tests [aspartate aminotransferase (AST) and alanine aminotransferase (ALT), total protein and albumin] (Heibashy et al., 2011; Sharma et al., 2013 and Lee et al., 2016), lipid profile [total cholesterol, triglycerides, high density cholesterol (HDL-Ch) and low density cholesterol (LDL-Ch)] (Gupta et al., 2009 and Mansour, 2013) and thyroid profile [free triiodothyronine $\left(\mathrm{FT}_{3}\right)$ and free thyroxin ( $\left.\mathrm{FT}_{4}\right)$ ] (Heibashy et al., 2011).

Radiation-induced cardiovascular disease (CVD) is seen as a long-term effect of radiation (Adams et al., 2003). Cardiovascular pathologies associated with radiation include myocardial infarct, congestive heart disease, pericarditis, vascular abnormalities, atherosclerosis, valvular heart disease, arrhythmias etc. (Gupta et al., 2009). Also, radiation-related excess of CVD mortality and morbidity was 
observed in life span studies among Japanese atomic bomb survivors (Mansour, 2013). Radiation-induced CVD is of concern for radiotherapy patients. A substantial risk of CVD mortality by myocardial infarctions and ischemic heart disease was observed after radiotherapy for Hodgkin disease (Swerdlow et al., 2007). High doses of ionizing radiation ranging from 3 to 17 Gy that were used to treat left sided breast cancer patients have been associated with longterm risk of cardiac pathology such as diffused fibrotic injury to the pericardium and myocardium (Andratschke et al., 2011).

However, exposure of the body to ionizing radiation produces reactive oxygen species (ROS) that damage protein, lipids and nucleic acids. Because of the lipid component in the membrane, lipid peroxidation is reported to be particularly susceptible to radiation damage (Kiang et al., 2009). However, Heibashy et al. (2011) reported that free radicals resulting from exposure to radiation accompanied by a decrease of glutathione peroxidase, catalase and superoxide dismutase (SOD). Also, Heibashy et al. (2011) observed an increase of malondialdhyde (MDA) in few hours after radiation exposure. Exposure of rats to gamma-irradiation (6Gy) caused a significant decrease in the glutathione level (GSH) and glutathione peroxidase enzyme activity (GSHpx) as well as catalase (CAT) associated with a significant elevation in malondialhyde (MDA) in liver and heart tissues compared to normal control rats group (Sharma et al., 2013).

Use of medicinal plants in radiation protection and recovery: A large number of drugs have been screened for their radioprotective efficacy, however, because of the inherent toxicity at useful concentrations, none of them could find clinical acceptance (Singh \& Yadav, 2005).

Ginseng (Panax ginseng), with thousands of years of history, has been traditionally known as a medicinal plant with mysterious powers in the Orient (Jagetia,
2007). The pharmacological properties of ginseng are attributed to ginsenosides, also referred to as steroid saponins that are found in extracts of ginseng. The pharmacological effects of ginseng extracts and ginsenosides have been reported in immunology, cancer, arteriosclerosis, hypertension and diabetes (Shalaby \& Hamouda, 2013 and Heibashy et al., 2014). They reported that ginseng has an effect on obesity and lipid metabolism in rats. Furthermore, Several recent researches noted that Panax ginseng extract has a radioprotective impact against radiation induced liver damage (Anees et al., 2014 and Deniz-Uluısık \& Keskin, 2016).

Green tea (Camellia sinensis) is one of the most popular beverages consumed worldwide. Green tea contains polyphenols, which include flavanols, flavandiols, flavonoids and phenolic acids; these compounds may account for up to $30 \%$ of the dry weight. Most of the green tea polyphenols are flavonols, commonly known as catechins (Vinson, 2000). There are four kinds of catechins mainly find in green tea: epicatechin, epigallocatechin, epicatechin-3gallate and EGCG (Sano et al., 2001). The preparation methods influence the catechins both quantitatively and qualitatively; the amount of catechins also varies in the original tea leaves due to differences in variety, origin and growing conditions (Hewala, 2015 and Choi et al., 2016).

Cinnamon (Cinnamomum zeylanicum) is used to flavor most foods in Arabian countries (Said \& Husein, 2009), it's widely used in food products. It has exhibited beneficial properties to health, such as antimicrobial activity, for controlling glucose intolerance and diabetes, inhibiting the proliferation of various cancer cell lines and for treating the common cold (Heibashy et al., 2014). The essential leaf oil of cinnamon is rich in eugenol, linalool and eugenyl acetate as well as further aroma-active volatiles, responsible for the pleasant cinnamon (Akbarzadeh et al., 2015). 
The objective of the current investigation was conducted to clarify the possible correction in the estimated parameters as a result of exposure to ionizing radiation in rats after treatment with medicinal plants. The underlying mechanisms through those antioxidants that counteracted in irradiated rats were discussed according to available published researches.

\section{MATERIALS AND METHODS Gamma irradiation:}

Whole body irradiation was performed in an indoor cobalt-60 unit (Gamma cell-22) at National Centre for Radiation Research and Technology, Egyptian Atomic Energy Authority, Nasr City, Cairo, Egypt. Irradiation did not include the time of ascent and descent. Corrections for physical decay and level of radiation exposure were calculated. Whole body irradiation was carried out by placing every animal in nylon bag being centrally located in the sample chamber of the gamma cell. Whole body irradiation was delivered for the required calculated exposure time at the level of 6Gy (shot dose). The dose rate was $0.794 \mathrm{~Gy} / \mathrm{min}$ at the time of experimentation.

\section{Animals:}

Seventy male albino rats (age 12 weeks) were obtained from the animal house of Nuclear Research Centre, Inshas, Egypt. All animals were fed on a standard rodent diet. They were fed commercial food pellets and provided with tap water ad libitum. All animal procedures were carried out in accordance with the guidelines of the Ethics Committee at the Nuclear Research Centre conformed to the "Guide for the care and use of Laboratory Animals" published by the US National Institutes of Health.

\section{Medicinal plants:}

Three medicinal plants were employed in this study. They were ginseng (Ginseng Panax) roots, green tea (Camellia sinensis) leaves and cinnamon (Cinnamomum zeylanicum) bark and obtained from local market (Harraz Herbs Market in Nasr City, Cairo, Egypt). The medicinal plants were grinded mechanically and sieved prior to their extraction.

Aqueous hydro-distilled extracts of ginseng (Ginseng Panax) roots (Mansour, 2013), green tea (Camellia sinensis) leaves (Heibashy et al., 2013a) and cinnamon (Cinnamomum zeylanicum) bark (Heibashy et al., 2013b) were prepared by simple distillation. In brief; $5 \mathrm{~g}$ of dried fine powder of each herb was boiled in $100 \mathrm{ml}$ deionized distilled water $(5 \%)$ for 15 minutes and left until cooled then the extractions were filtered through Milipore 0.2 microns filter prior to use. The aqueous filtrated extractions were preserved in dark bottle and stored at $4 \mathrm{C}^{\circ}$.

\section{Experimental design:}

The study included two experiments; the first one carried out to follow up the changes that could occur in liver, heart, lipid and thyroid profiles as well as antioxidant and lipid peroxidation status as a result of exposure to gamma irradiation. To achieve this purpose, a comparison was carried out between a group of five normal control rats and five irradiated rats (First experiment).

In the second experiment (60 rats), six comparisons were made between normal control rats [non-irradiated (10 rats)] and five subgroups of irradiated rats (50 rats); 10 rats in each one. The first experimentally irradiated rats subgroup was served as recovery group. The second irradiated rats subgroup rats were treated intragastrically with $10 \mathrm{ml}(5 \%)$ extract of ginseng (Ginseng Panax) roots daily for one month and served as ginseng subgroup. The third irradiated rats subgroup rats were treated intragastrically with $10 \mathrm{ml} \quad(5 \%)$ extract of green tea (Camellia sinensis) leaves daily for one month and served as green tea subgroup. The fourth irradiated rats subgroup rats were treated intragastrically with $10 \mathrm{ml} \quad(5 \%)$ extract of cinnamon (Cinnamomum zeylanicum) bark daily for one month and served as cinnamon subgroup. The fifth irradiated rats subgroup 
rats were treated intragastrically with $10 \mathrm{ml}$ $(5 \%)$ extracts mixture of ginseng, green tea and cinnamon daily for the same previous period and served as combined extracts subgroup. This experiment was divided into two intervals ( 15 and 30 days; five rats in each interval).

At the end of the experimental period, animals were scarified and blood was collected in a clean dry tube to obtain serum for determination of liver function [alanine transferase (ALT), aspartate transferase (AST), total protein, albumin and globulin], cardiac function [lactate dehydrogenase $(\mathrm{LDH})$ and creatine kinase (CK)], lipid profile [total cholesterol, triglycerides, high density cholesterol (HDL-Ch) and low density cholesterol (LDL-Ch)] and thyroid profile [free triiodothyronine $\left(\mathrm{FT}_{3}\right)$ and free thyroxine $\left(\mathrm{FT}_{4}\right)$ levels].

Biochemical Analysis Serum ALT, AST, total protein, albumin, total cholesterol, triglycerides, HDL-Ch and LDL-Ch were assayed colorimetrically using commercial kits (DIACHEM Ltd., Budapest, Hungary). Serum free triiodothyronine $\left(\mathrm{FT}_{3}\right)$ and free thyroxine $\left(\mathrm{FT}_{4}\right)$ concentrations were estimated by radioimmunoassay (RIA) using solid phase component system. The kits were purchased from Institute of Isotopes Ltd. Budapest, Hungary.

After sacrifice, livers and hearts were quickly removed, weighed and perfused by ice-cold sterile $0.15 \mathrm{M} \mathrm{KCl}$ and then homogenized. The supernatants were filtered for estimations of liver and heart glutathione (GSH) contents, glutathione peroxidation (Gpx) activities and lipid peroxidation (TBARS) levels. GSH, Gpx and TBARS were assayed by ELISA (Sandwich Immunoassay Technique) using commercial kits (BioVision Incorporated, Milpitas, USA)

Data were statistically analyzed using student's t-test in the first experimental and analysis of variance (ANOVA) followed by Duncan's multiple range test in the second experimental according to Snedecor \&
Cochran (1982). The data are tabulated as mean \pm standard error.

\section{RESULTS \& DISCUSSION}

The ionizing radiation is more far harmful than non-ionizing radiation. The radiation effect produced by exposure ionizing radiation affects people by depositing energy in body tissue which can cause cell damage or cell death. In other cases the cell may survive but become abnormal either temporarily or permanently or an abnormal cell may become malignant (Verma et al., 2011). A very small amount of ionizing radiation could trigger cancer in long term even though it may take decades for cancer to appear and other effect with long term is changes in DNA called mutations (Ezz, 2011).

A disturbance in pro-oxidant/anti-oxidant systems results from a myriad of different oxidative challenges, including radiation. The generations of free radicals result in imbalance of the pro-oxidant and antioxidant activities ultimately result in cell death (Umadevi et al., 2013 and Heibashy et al., 2014).

Data in Table (1) demonstrated that exposing male albino rats to gammairradiation (6Gy) showed a significant elevation in serum ALT and AST as compared to their corresponding control rats group. The increase ALT and AST may be due to the damage of all the tissues including reticulo endothelial tissue, hepatic parenchyma, arteries and capsule are affected in the liver after irradiation to high doses of gamma radiation which in turn, leads to an elevation in the permeability of cell membranes, and facilitates the passage of cytoplasmic enzymes outside the cells, leading to increase in the aminotransferase activities in liver and blood serum. Moreover, these results may be attributed to the destructive effect of gamma rays on vital biological processes especially in the liver as a result of deficiency in antioxidant system, liver MDA levels were increased. 
Table (1): Effects of $y$-radiation on studied parameters in rats (Mean $\pm \mathrm{SE}$ ).

\begin{tabular}{|c|c|c|c|c|}
\hline & $\begin{array}{l}\text { Groups } \\
\text { Parameters }\end{array}$ & $\begin{array}{l}\text { Control } \\
n=10\end{array}$ & $\begin{array}{l}\text { Irradiated } \\
\mathrm{n}=10\end{array}$ & $\begin{array}{l}\% \text { of } \\
\text { change }\end{array}$ \\
\hline \multirow{5}{*}{ 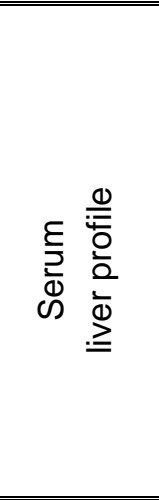 } & $\begin{array}{c}\begin{array}{c}\text { Serum AST } \\
(\mathrm{U} / \mathrm{L})\end{array} \\
\end{array}$ & $121.873 \pm 3.624$ & $253.707 \pm 10.549^{*}$ & 108.17 \\
\hline & $\begin{array}{c}\text { Serum ALT } \\
(\mathrm{U} / \mathrm{L})\end{array}$ & $24.136 \pm 1.278$ & $229.841 \pm 9.205^{\star}$ & 852.27 \\
\hline & $\begin{array}{c}\text { Serum total protein } \\
(\mathrm{g} / \mathrm{dL})\end{array}$ & $6.198 \pm 0.097$ & $3.755 \pm 0.061^{*}$ & -39.42 \\
\hline & $\begin{array}{c}\text { Serum albumin } \\
(\mathrm{g} / \mathrm{dL})\end{array}$ & $4.156 \pm 0.041$ & $2.013 \pm 0.021^{*}$ & -51.56 \\
\hline & $\begin{array}{l}\text { Serum globulin } \\
(\mathrm{g} / \mathrm{dL})\end{array}$ & $2.042 \pm 0.022$ & $1.742 \pm 0.015^{*}$ & -14.69 \\
\hline \multirow{2}{*}{ 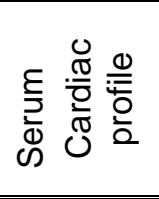 } & $\begin{array}{c}\text { Serum LDH } \\
(\mathrm{U} / \mathrm{L})\end{array}$ & $233.192 \pm 5.472$ & $449.829 \pm 11.327^{*}$ & 92.90 \\
\hline & $\begin{array}{c}\text { Serum CK } \\
(\mathrm{U} / \mathrm{L})\end{array}$ & $92.338 \pm 2.104$ & $191.221 \pm 5.413^{*}$ & 107.09 \\
\hline \multirow{4}{*}{ 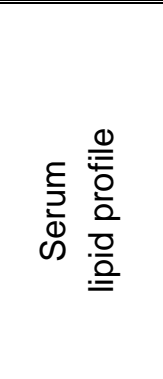 } & Serum cholesterol (mg/dL) & $55.873 \pm 0.839$ & $109.407 \pm 1.478^{*}$ & 95.81 \\
\hline & Serum triglycerides $(\mathrm{mg} / \mathrm{dL})$ & $64.136 \pm 0.928$ & $137.841 \pm 1.749^{*}$ & 114.92 \\
\hline & $\begin{array}{c}\text { Serum HDL-Ch } \\
(\mathrm{mg} / \mathrm{dL})\end{array}$ & $14.553 \pm 0.021$ & $21.718 \pm 0.056^{\star}$ & 49.23 \\
\hline & $\begin{array}{c}\text { Serum LDL-Ch } \\
(\mathrm{mg} / \mathrm{dL})\end{array}$ & $28.493 \pm 0.032$ & $60.121 \pm 0.098^{\star}$ & 111.00 \\
\hline \multirow{2}{*}{ 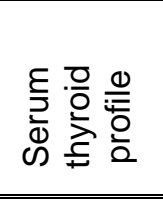 } & $\begin{array}{c}\mathrm{FT}_{3} \\
(\mathrm{pg} / \mathrm{ml}) \\
\end{array}$ & $1.178 \pm 0.011$ & $0.528 \pm 0.003^{*}$ & -55.18 \\
\hline & $\begin{array}{c}\mathrm{FT}_{4} \\
\text { (ng/dL) } \\
\end{array}$ & $0.529 \pm 0.003$ & $0.513 \pm 0.003$ & -3.02 \\
\hline \multirow{3}{*}{ 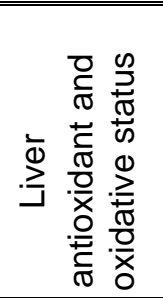 } & $\begin{array}{c}\text { GSH } \\
\text { (mg/g tissue) }\end{array}$ & $27.562 \pm 0.184$ & $14.971 \pm 0.095^{\star}$ & -45.68 \\
\hline & $\begin{array}{c}\text { Gpx } \\
(\mu \mathrm{mol} / \mathrm{min} / \mathrm{g} \text { tissue })\end{array}$ & $129.527 \pm 1.328$ & $78.524 \pm 0.806^{*}$ & -39.38 \\
\hline & $\begin{array}{c}\text { TBARS } \\
\text { (nmol/100 mg tissue) }\end{array}$ & $1.826 \pm 0.017$ & $4.413 \pm 0.039^{*}$ & 181.68 \\
\hline \multirow{3}{*}{ 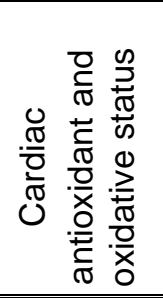 } & $\begin{array}{c}\text { GSH } \\
\text { (mg/g tissue) } \\
\end{array}$ & $14.731 \pm 0.122$ & $8.182 \pm 0.058^{\star}$ & -44.46 \\
\hline & $\begin{array}{c}\text { Gpx } \\
(\mu \mathrm{mol} / \mathrm{min} / \mathrm{g} \text { tissue })\end{array}$ & $72.328 \pm 0.813$ & $55.352 \pm 0.543^{*}$ & -23.47 \\
\hline & $\begin{array}{c}\text { TBARS } \\
\text { (nmol/100 mg tissue) }\end{array}$ & $1.117 \pm 0.009$ & $2.836 \pm 0.021^{*}$ & 153.89 \\
\hline
\end{tabular}

- $\mathrm{n}=$ number of rats.

- $\left.{ }^{*}\right)$ refer to significance $(P<0.001)$. 
Also, the significant $(P<0.05)$ decrease in serum levels of protein, albumin and globulin after exposing rats to (6Gy) of $\mathrm{y}$-irradiation (Table 1 and). These data might be due to the result of denaturation of proteins, interruption of mitosis, chromosomal aberration and increase of oxidative stress which induced liver cells injury which associated with a pronounce of a decrease synthesis of protein in liver, increase of protein catabolic rate, elevation in the breakdown of $\mathrm{SH}$-bound and decline in glutathione pool. These data are in harmony with several authors (Heibashy \& Sharoud, 2008; Heibashy et al., 2011 and Masour 2013).

lonizing radiation is known to induce oxidative stress through generation of ROS in an imbalance in pro-oxidant, antioxidant status in the cells (Bhosle et al., 2005). In this study, the exposure to gammairradiation (6Gy) caused a marked increase in serum activities of LDH and CPK (Table 1). These data may be attributed to radiolytic products of water including hydroxyl and hydroperoxide radicals can initiate lipid peroxidation in the heart, activation of lysosomal enzymes and hyperlipdemia. These data are in parallel with Bhosle et al. (2005) and Masour (2013). They explained these results to the excessive production of free radicals and lipid peroxides might have caused the leakage of cytosolic enzymes such as lactate dehydrogenase and creatine kinase associated with excessive calcium influx with ensuring cellular dysfunction and death from calcium overload.

In this study, all the major classes of serum lipid and lipoprotein were significantly increased in irradiated rats over those of the control (Table 1). These results are in harmony with those obtained by Heibashy \& Sharoud (2008) and Heibashy et al. (2011). They attributed the hyperlipdemic action as a result of exposure to gamma irradiation which causes the activation of cholesterol synthesis and mobilization of lipid content in bone marrow. The intensity of hyperlipidemic state found in this study may reflect the degree of stress imposed on the animal, which might be indicative of the response of the specific radiosensitive structures such as bone marrow (Heibashy \& Sharoud, 2008) or reflects on increase requirement for fat by irradiated rats (Heibashy et al., 2011) as well as, disturbance in the levels of leptin and adiponectin associated with changes in the hypothalamus-pituitary-thyroid axis (HPTA) and neuropeptide hormones such as NPY, orexin-A and orexin-B (Heibashy et al., 2010).

In the current study, the reciprocal relationship between the concentrations of thyroid hormones (Free $T_{3}$ and Free $T_{4}$ ) in serum and hyperlipidemia (induced by exposure to gamma rays) is evident and depends on the percent of fat content (Table 1). These results seemed to be in complete accordance with recent studies made by ElMissiry et al. (2007); Heibashy \& Sharoud (2008); Gupta et al. (2009) and Mansour (2013).

Our choice of serum free $T_{3}$ and free $T_{4}$ as the best in vitro tests of thyroid function was based on the following fact: serum free $\mathrm{T}_{3}$ and free $_{4}$ concentrations may be expected to reflect the actual thyroid status more than total $\mathrm{T}_{3}\left(\mathrm{TT}_{3}\right)$ and total $\mathrm{T}_{4}\left(\mathrm{TT}_{4}\right)$ concentrations because of the dependence of $\mathrm{TT}_{3}$ and $\mathrm{TT}_{4}$ values on plasma protein binding which almost bind all thyroid hormones liberated from the thyroid gland leaving free $T_{3}$ and free $T_{4}$ relatively unchanged in healthy subjects (Chaput et al., 2008).

In table (1) showed a significant decrease in the level of free $T_{3}$ while, a numerical changed was occurred in the level of free $T_{4}$. These results may be due to the conversion of $T_{3}$ to $T_{4}$ or/and conversion of reverse $\left(r T_{3}\right)$ to $T_{4}$ as a result of exposure to gamma radiation causing hypothyroidism. This later results confirmed the statement said by Liu et al. (2009) that "Free $\mathrm{T}_{3}$ is 
considered to be the major biologic mediator of the thyroid function test".

The current study revealed that significant decrease in the contents of liver and cardiac GSH (glutathione) and the activities of Gpx(glutathione peroxidase) and elevation in the levels of liver and cardiac TBARS as a result of exposure to 6Gy gamma radiation (Table 1 ). These results may be attributed to the destructive effect of gamma rays on vital biological processes in the liver and heart tissues. Moreover, these data may be due to the destructive effect of gamma rays on vital biological processes especially in the liver which is the main source of albumin and protein production in the body. Also, gamma rays accelerate the degradation of albumin and protein. The injure in the hepatic cells as a result to exposure to gamma rays led to increment free radical production associated with deficient in the antioxidant system. As a result of deficiency in antioxidant system, liver and heart TBARS levels were increased (Table 1). These results are in harmony with those obtained by Heibashy et al. (2011) and Sharma et al. (2013).

Also, Sharma et al. (2013) postulated that gamma irradiation $6 \mathrm{~Gy}$ caused a considerable decrease in glutathione content and the activities of glutathione peroxidase and catalase associated with a remarkable elevation in the level of malondialhyde (MDA) in liver and heart tissues compared to normal control mice group.

In recent years, it has become well known that antioxidant phytochemicals are present in plants, fruits and vegetables. Indeed, herbal medicine such as ginseng
(Panax ginseng) (Mansour, 2013 and Anees et al., 2014), green tea (Camellia sinensis) (Abd El-Megid, 2014 and Choi et al., 2016) and cinnamon (Cinnamomum zeylanicum) (Vangalapati et al., 2012 and Shalaby \& Saifan, 2014) is generally considered a wellestablished form of complementary medicine.

The supplementation of ginseng, green tea or cinnamon led to a remarkable improvement in all studied parameters in irradiated animals. These data may be attributed to the improvement in the physical and chemical properties of them dependent on the time of treatment (15 and 30 days). These improvements in all parameters were recorded in Tables (2-4). So, the results from the current investigation indicated that ginseng, green tea or cinnamon treatment protects against radiation damage by inhibiting radiation-induced oxidative stress and liver/cardiac dysfunctions by decreasing liver/cardiac TBARS and ameliorating the antioxidant system (GSH and Gpx) in liver and cardiac tissues.

In the current study, the maximum correction was occurred in all studied parameters in irradiated-rats treated with mixture of ginseng, green tea and cinnamon dependent on the time of treatment (15 and 30 days). These data were recorded in Tables (2-4). These results may be attributed to the synergistic effects of ginseng, green tea and cinnamon antioxidants which act as radio-protective agents due to the potential powerful of their antioxidants properties and to the pharmakinetic and pharmadynamic properties. 
Hammam, et al.,

Table (2): Therapeutic role of ginseng, green tea or cinnamon and their mixture against hazard effects of $\mathrm{y}$-radiation on liver and cardiac function profiles in rats (Mean \pm SE).

\begin{tabular}{|c|c|c|c|c|c|c|}
\hline \multirow[b]{2}{*}{ Interval } & Control & $\begin{array}{l}\text { Irradiated } \\
\text { recover }\end{array}$ & $\begin{array}{c}\text { Irradiated } \\
+ \\
\text { ginseng }\end{array}$ & $\begin{array}{c}\text { Irradiated + } \\
\text { green tea }\end{array}$ & $\begin{array}{l}\text { Irradiated + } \\
\text { cinnamon }\end{array}$ & $\begin{array}{l}\text { Irradiated + } \\
\quad \text { Mixture }\end{array}$ \\
\hline & \multicolumn{6}{|c|}{$\mathrm{AST}(\mathrm{U} / \mathrm{L})$} \\
\hline $\begin{array}{c}15 \text { days } \\
n=5\end{array}$ & $\begin{array}{l}122.147 \\
\pm 3.631_{a}^{\mathrm{A}}\end{array}$ & $\begin{array}{r}210.439 \\
\pm 8.775^{\mathrm{B}} \mathrm{a} \\
\end{array}$ & $\begin{array}{r}180.522 \\
\pm 7.003^{\mathrm{C}} \mathrm{a} \\
\end{array}$ & $\begin{array}{r}184.439 \\
\pm 7.095^{\mathrm{C}} \mathrm{a} \\
\end{array}$ & $\begin{array}{l}186.106 \\
\pm 7.112^{\mathrm{C}} \mathrm{a}\end{array}$ & $\begin{array}{r}169.524 \\
\pm 5.659^{\mathrm{D}} \mathrm{a} \\
\end{array}$ \\
\hline $\begin{array}{c}30 \text { days } \\
\mathrm{n}=5\end{array}$ & $\begin{array}{l}124.023 \\
\pm 3.639^{A}{ }_{a}\end{array}$ & $\begin{array}{c}179.327 \\
\pm 6.981_{b}^{B}\end{array}$ & $\begin{array}{r}159.701 \\
\pm 5.697^{C}{ }_{b}\end{array}$ & $\begin{array}{r}170.559 \\
\pm 6.311^{D_{b}}\end{array}$ & $\begin{array}{r}171.201 \\
\pm 6.358^{\mathrm{D}}{ }_{\mathrm{b}}\end{array}$ & $\begin{array}{c}140.327 \\
\pm 4.469^{\mathrm{E}}{ }_{\mathrm{b}}\end{array}$ \\
\hline \multirow[b]{2}{*}{$\begin{array}{c}15 \text { days } \\
n=5\end{array}$} & \multicolumn{6}{|c|}{$\mathrm{ALT}(\mathrm{U} / \mathrm{L})$} \\
\hline & $\begin{array}{r}24.135 \\
\pm 1.274^{\mathrm{A}} \\
\end{array}$ & $\begin{array}{r}177.299 \\
\pm 7.101^{\mathrm{B}} \mathrm{a} \\
\end{array}$ & $\begin{array}{r}110.364 \\
\pm 5.892^{\mathrm{C}}{ }_{\mathrm{a}} \\
\end{array}$ & $\begin{array}{r}132.247 \\
\pm 6.225^{\mathrm{D}} \\
\end{array}$ & $\begin{array}{r}136.491 \\
\pm 6.297_{a}^{\mathrm{D}} \\
\end{array}$ & $\begin{array}{r}85.627 \\
\pm 4.064{ }_{\mathrm{a}} \\
\end{array}$ \\
\hline $\begin{array}{c}30 \text { days } \\
n=5\end{array}$ & $\begin{array}{r}24.139 \\
\pm 1.277^{\mathrm{A}} \\
\end{array}$ & $\begin{array}{r}105.556 \\
\pm 5.068^{B}{ }_{b}\end{array}$ & $\begin{array}{r}62.473 \\
\pm 3.192^{\mathrm{B}} \\
\end{array}$ & $\begin{array}{r}88.737 \\
\pm 4.399^{\mathrm{B}}{ }_{\mathrm{b}} \\
\end{array}$ & $\begin{array}{r}90.448 \\
\pm 4.416^{\mathrm{B}}{ }_{\mathrm{b}}\end{array}$ & $\begin{array}{r}38.816 \\
\pm 2.352{ }_{b} \\
\end{array}$ \\
\hline & \multicolumn{6}{|c|}{ Total protein $(\mathrm{g} / \mathrm{dL})$} \\
\hline $\begin{array}{c}15 \text { days } \\
n=5\end{array}$ & $\begin{array}{c}6.203 \\
\pm 0.095^{\mathrm{A}}{ }_{\mathrm{a}}\end{array}$ & $\begin{array}{c}4.054 \\
\pm 0.072^{\mathrm{B}} \text { a } \\
\end{array}$ & $\begin{array}{c}4.927 \underset{c}{ \pm 0.082} \\
a\end{array}$ & $\begin{array}{c}4.576 \pm 0.081 \\
D \\
a\end{array}$ & $\begin{array}{r}4.569 \\
\pm 0.081^{\mathrm{D}} \\
\end{array}$ & $\begin{aligned} & 5.137 \\
& \pm 0.086{ }^{E} \\
&\end{aligned}$ \\
\hline $\begin{array}{c}30 \text { days } \\
\mathrm{n}=5\end{array}$ & $\begin{aligned} & 6.197 \\
& \pm 0.095^{\mathrm{A}}{ }_{\mathrm{a}} \\
&\end{aligned}$ & $\begin{aligned} & 4.568 \\
& \pm 0.079^{\mathrm{B}} \\
&\end{aligned}$ & $\begin{array}{c}5.498 \\
\pm 0.089^{C}{ }_{b}\end{array}$ & $\begin{array}{r}5.105 \\
\pm 0.085^{\mathrm{D}} \\
\end{array}$ & $\begin{array}{r}5.093 \\
\pm 0.084^{\mathrm{D}} \\
\end{array}$ & $\begin{array}{r}6.199 \\
\pm 0.092^{\mathrm{A}} \mathrm{b} \\
\end{array}$ \\
\hline \multirow[b]{2}{*}{$\begin{array}{c}15 \text { days } \\
n=5\end{array}$} & \multicolumn{6}{|c|}{ Albumin (g/dL) } \\
\hline & $\begin{aligned} & 4.153 \\
& \pm 0.043^{\mathrm{A}} \mathrm{a} \\
&\end{aligned}$ & $\begin{array}{r}2.259 \\
\pm 0.028^{\mathrm{B}} \mathrm{a} \\
\end{array}$ & $\begin{array}{r}2.883 \\
\pm 0.034_{\mathrm{a}}^{\mathrm{C}} \\
\end{array}$ & $\begin{array}{r}2.569 \\
\pm 0.031^{\mathrm{D}} \\
\end{array}$ & $\begin{array}{r}2.562 \\
\pm 0.031_{\mathrm{a}}^{\mathrm{D}} \\
\end{array}$ & $\begin{array}{r}3.104 \\
\pm 0.036^{\mathrm{E}}{ }_{\mathrm{a}} \\
\end{array}$ \\
\hline $\begin{array}{c}30 \text { days } \\
\mathrm{n}=5\end{array}$ & $\begin{aligned} & 4.157 \\
& \pm 0.044^{\mathrm{A}} \\
&\end{aligned}$ & $\begin{array}{r}2.721 \\
\pm 0.032^{\mathrm{B}}{ }_{\mathrm{b}} \\
\end{array}$ & $\begin{array}{r}3.631 \\
\pm 0.028^{C}{ }_{b} \\
\end{array}$ & $\begin{array}{r}3.104 \\
\pm 0.035^{\mathrm{D}} \\
\end{array}$ & $\begin{array}{r}3.089 \\
\pm 0.034_{b}^{\mathrm{D}} \\
\end{array}$ & $\begin{array}{r}4.146 \\
\pm 0.041^{\mathrm{A}} \mathrm{b} \\
\end{array}$ \\
\hline \multirow[b]{2}{*}{$\begin{array}{c}15 \text { days } \\
n=5\end{array}$} & \multicolumn{6}{|c|}{ Globulin (g/dL) } \\
\hline & $\begin{array}{r}2.050 \\
\pm 0.022^{\mathrm{A}}{ }_{\mathrm{a}} \\
\end{array}$ & $\begin{array}{r}1.795 \\
\pm 0.016^{\mathrm{B}} \\
\end{array}$ & $\begin{array}{r}2.044 \\
\pm 0.020^{\mathrm{A}} \\
\end{array}$ & $\begin{array}{r}2.007 \\
\pm 0.016_{\mathrm{a}}^{\mathrm{A}} \\
\end{array}$ & $\begin{array}{r}2.007 \\
\pm 0.017^{\mathrm{A}} \\
\end{array}$ & $\begin{array}{r}2.033 \\
\pm 0.019^{\mathrm{A}} \\
\end{array}$ \\
\hline $\begin{array}{c}30 \text { days } \\
n=5\end{array}$ & $\begin{array}{r}2.040 \\
\pm 0.021^{\mathrm{A}} \mathrm{a}\end{array}$ & $\begin{array}{r}1.847 \\
\pm 0.017_{b}^{B}\end{array}$ & $\begin{array}{r}1.867 \\
\pm 0.016^{\mathrm{B}} \mathrm{b}\end{array}$ & $\begin{array}{r}2.001 \\
\pm 0.017^{\mathrm{A}}{ }_{\mathrm{a}}\end{array}$ & $\begin{array}{r}2.004 \\
\pm 0.017^{\mathrm{A}} \mathrm{a}\end{array}$ & $\begin{array}{r}2.053 \\
\pm 0.017^{\mathrm{A}} \mathrm{a}\end{array}$ \\
\hline \multirow[b]{2}{*}{$\begin{array}{c}15 \text { days } \\
n=5\end{array}$} & \multicolumn{6}{|c|}{$\mathrm{LDH}(\mathrm{U} / \mathrm{L})$} \\
\hline & $\begin{array}{l}232.554 \\
\pm 5.412^{\mathrm{A}} \\
\end{array}$ & $\begin{array}{r}393.438 \\
\pm 10.114_{a}^{\mathrm{B}} \\
\end{array}$ & $\begin{array}{l}300.522 \\
\pm 7.932^{\mathrm{C}} \\
\end{array}$ & $\begin{array}{c}349.019 \\
\pm 9.095^{\mathrm{D}}\end{array}$ & $\begin{array}{l}351.897 \\
\pm 9.004^{\mathrm{D}} \\
\end{array}$ & $\begin{array}{r}262.524 \\
\pm 5.845^{\mathrm{E}} \mathrm{a} \\
\end{array}$ \\
\hline $\begin{array}{c}30 \text { days } \\
\mathrm{n}=5\end{array}$ & $\begin{array}{r}231.878 \\
\pm 5.399^{\mathrm{A}}{ }_{\mathrm{a}} \\
\end{array}$ & $\begin{array}{r}301.672 \\
\pm 8.021^{B}{ }_{b} \\
\end{array}$ & $\begin{array}{r}251.885 \\
\pm 5.697^{C}{ }_{b} \\
\end{array}$ & $\begin{array}{r}298.559 \\
\pm 6.457^{\mathrm{D}}{ }_{b} \\
\end{array}$ & $\begin{array}{r}302.201 \\
\pm 6.555^{\mathrm{D}}{ }_{\mathrm{b}} \\
\end{array}$ & $\begin{array}{r}235.327 \\
\pm 5.409^{A} \\
\end{array}$ \\
\hline \multirow[b]{2}{*}{$\begin{array}{c}15 \text { days } \\
n=5\end{array}$} & \multicolumn{6}{|c|}{ CK (U/L) } \\
\hline & $\begin{array}{r}92.008 \\
\pm 2.065^{\mathrm{A}} \mathrm{a} \\
\end{array}$ & $\begin{array}{c}170.293 \\
\pm 4.869^{\mathrm{B}} \mathrm{a}\end{array}$ & $\begin{array}{c}132.396 \\
\pm 3.537^{\mathrm{C}} \\
\end{array}$ & $\begin{array}{c}152.061 \\
\pm 4.319^{\mathrm{D}}\end{array}$ & $\begin{array}{c}152.329 \\
\pm 4.328^{\mathrm{D}}\end{array}$ & $\begin{array}{c}111.033 \\
\pm 3.537^{\mathrm{E}}\end{array}$ \\
\hline $\begin{array}{c}30 \text { days } \\
\mathrm{n}=5\end{array}$ & $\begin{array}{r}91.859 \\
\pm 2.037_{\mathrm{a}}^{\mathrm{A}}\end{array}$ & $\begin{array}{r}154.632 \\
\pm 4.217^{\mathrm{B}}\end{array}$ & $\begin{array}{r}108.763 \\
\pm 3.438^{\mathrm{C}}{ }_{b}\end{array}$ & $\begin{array}{c}119.028 \\
\pm 3.623^{\mathrm{D}}\end{array}$ & $\begin{array}{c}120.004 \\
\pm 3.641^{\mathrm{D}}{ }_{\mathrm{a}}\end{array}$ & $\begin{array}{r}92.119 \\
\pm 2.047^{\mathrm{A}}\end{array}$ \\
\hline
\end{tabular}

$-A, B, C, D, E$ Means with a common superscript within a row are significantly different at $(P<0.05)$.

- $a, b$ Means with a common subscript within a column are significantly different at $(P<0.05)$. 
Table (3): Therapeutic role of ginseng, green tea or cinnamon and their mixture against hazard effects of $\mathrm{Y}$-radiation on lipid and thyroid hormones profiles in rats.

\begin{tabular}{|c|c|c|c|c|c|c|}
\hline Treatment & Control & $\begin{array}{l}\text { Irradiated } \\
\text { recover }\end{array}$ & $\begin{array}{c}\text { Irradiated } \\
+ \\
\text { ginseng }\end{array}$ & $\begin{array}{c}\text { Irradiated + } \\
\text { green tea }\end{array}$ & $\begin{array}{l}\text { Irradiated + } \\
\text { Cinnamon }\end{array}$ & $\begin{array}{c}\text { Irradiated + } \\
\text { Mixture }\end{array}$ \\
\hline atrat & \multicolumn{6}{|c|}{ Serum cholesterol (mg/dL) } \\
\hline $\begin{array}{c}15 \text { days } \\
n=5\end{array}$ & $\begin{array}{r}55.493 \\
\pm 0.842^{\mathrm{A}} \\
\end{array}$ & $\begin{array}{r}98.548 \\
\pm 1.351^{\mathrm{B}} \\
\end{array}$ & $\begin{array}{r}80.771 \\
\pm 1.103^{\mathrm{C}} \\
\end{array}$ & $\begin{array}{r}85.404 \\
\pm 1.278^{\mathrm{D}} \\
\end{array}$ & $\begin{array}{r}85.892 \\
\pm 1.288^{\mathrm{D}} \\
\end{array}$ & $\begin{array}{r}74.292 \\
\pm 1.351^{\mathrm{E}} \mathrm{a}\end{array}$ \\
\hline \multirow[t]{2}{*}{$\begin{array}{c}30 \text { days } \\
\mathrm{n}=5\end{array}$} & $\begin{array}{r}54.891 \\
\pm 0.837^{\mathrm{A}} \\
\end{array}$ & $\begin{array}{r}81.692 \\
\pm 1.211^{B} \\
\end{array}$ & $\begin{array}{r}68.545 \\
\pm 1.008^{C} \\
\end{array}$ & $\begin{array}{r}77.912 \\
\pm 1.078^{\mathrm{D}} \\
\end{array}$ & $\begin{array}{r}78.331 \\
\pm 1.081_{b}^{\mathrm{D}} \\
\end{array}$ & $\begin{array}{r}59.428 \\
\pm 0.942^{\mathrm{E}} \\
\end{array}$ \\
\hline & \multicolumn{6}{|c|}{ Serum triglycerides $(\mathrm{mg} / \mathrm{dL})$} \\
\hline $\begin{array}{c}15 \text { days } \\
n=5\end{array}$ & $\begin{array}{l}64.559 \\
\pm 0.937^{\mathrm{A}} \\
\end{array}$ & $\begin{array}{l}121.652 \\
\pm 1.621^{\mathrm{B}}{ }_{\mathrm{a}} \\
\end{array}$ & $\begin{array}{l}95.319 \\
\pm 1.318^{\mathrm{C}}\end{array}$ & $\begin{array}{l}100.897 \\
\pm 1.524_{a}^{\mathrm{D}} \\
\end{array}$ & $\begin{array}{l}102.004 \\
\pm 1.533^{\mathrm{D}} \\
\end{array}$ & $\begin{array}{l}88.727 \\
\pm 1.196^{\mathrm{E}} \\
\end{array}$ \\
\hline \multirow[t]{2}{*}{$\begin{array}{c}30 \text { days } \\
\mathrm{n}=5\end{array}$} & $\begin{array}{l}64.692 \\
\pm 0.952^{\mathrm{A}} \\
\end{array}$ & $\begin{array}{l}100.709 \\
\pm 1.511^{B}\end{array}$ & $\begin{array}{r}82.116 \\
\pm 1.089^{c} b\end{array}$ & $\begin{array}{l}85.921 \\
\pm 1.094_{b}^{D}\end{array}$ & $\begin{array}{l}86.117 \\
\pm 1.102^{\mathrm{D}} \\
\end{array}$ & $\begin{array}{l}70.556 \\
\pm 0.971^{E}\end{array}$ \\
\hline & \multicolumn{6}{|c|}{ Serum HDL-Ch (mg/dL) } \\
\hline $\begin{array}{c}15 \text { days } \\
n=5\end{array}$ & $\begin{array}{c}14.601 \\
\pm 0.022^{\mathrm{A}}{ }_{\mathrm{a}} \\
\end{array}$ & $\begin{array}{l}20.329 \\
\pm 0.051^{\mathrm{B}} \mathrm{a}\end{array}$ & $\begin{array}{c}17.117 \\
\pm 0.039^{\mathrm{C}} \\
\end{array}$ & $\begin{array}{l}18.652 \\
\pm 0.043^{\mathrm{D}} \\
\end{array}$ & $\begin{array}{l}18.713 \\
\pm 0.045^{\mathrm{D}} \\
\end{array}$ & $\begin{array}{l}16.218 \\
\pm 0.034^{\mathrm{E}}{ }_{\mathrm{a}}\end{array}$ \\
\hline \multirow[t]{2}{*}{$\begin{array}{c}30 \text { days } \\
\mathrm{n}=5\end{array}$} & $\begin{array}{r}14.578 \\
\pm 0.021^{\mathrm{A}}{ }_{\mathrm{a}}\end{array}$ & $\begin{array}{l}18.776 \\
\pm 0.046^{B}{ }_{b} \\
\end{array}$ & $\begin{array}{r}16.328 \\
\pm 0.046^{C} \mathrm{~b} \\
\end{array}$ & $\begin{array}{r}17.009 \\
\pm 0.046^{\mathrm{D}} \mathrm{b}\end{array}$ & $\begin{array}{r}17.106 \\
\pm 0.046^{\mathrm{D}} \mathrm{b}\end{array}$ & $\begin{array}{r}14.588 \\
\pm 0.029^{\mathrm{E}}{ }_{b}\end{array}$ \\
\hline & \multicolumn{6}{|c|}{ Serum LDL-Ch (mg/dL) } \\
\hline $\begin{array}{c}15 \text { days } \\
n=5\end{array}$ & $\begin{array}{r}27.980 \\
\pm 0.033_{\mathrm{A}}^{\mathrm{A}} \\
\end{array}$ & $\begin{array}{r}53.889 \\
\pm 0.091^{\mathrm{B}} \mathrm{a} \\
\end{array}$ & $\begin{array}{r}44.590 \\
\pm 0.077^{\mathrm{C}} \\
\end{array}$ & $\begin{array}{r}46.573 \\
\pm 0.080^{\mathrm{D}} \mathrm{a} \\
\end{array}$ & $\begin{array}{r}46.778 \\
\pm 0.081^{\mathrm{D}} \mathrm{a} \\
\end{array}$ & $\begin{array}{r}40.329 \\
\pm 0.066^{\mathrm{E}}{ }_{\mathrm{a}} \\
\end{array}$ \\
\hline \multirow[t]{2}{*}{$\begin{array}{c}30 \text { days } \\
\mathrm{n}=5 \\
\end{array}$} & $\begin{array}{r}27.365 \\
\pm 0.033^{\mathrm{A}} \\
\end{array}$ & $\begin{array}{r}42.774 \\
\pm 0.073^{B} \\
\end{array}$ & $\begin{array}{r}35.794 \\
\pm 0.054{ }^{c} b \\
\end{array}$ & $\begin{array}{r}43.719 \\
\pm 0.075^{\mathrm{D}} \\
\end{array}$ & $\begin{array}{r}44.002 \\
\pm 0.077_{b}^{D}\end{array}$ & $\begin{array}{r}30.729 \\
\pm 0.042^{E} b \\
\end{array}$ \\
\hline & \multicolumn{6}{|c|}{ FT3 (pg/ml) } \\
\hline $\begin{array}{c}15 \text { days } \\
n=5\end{array}$ & $\begin{array}{c}1.178 \\
\pm 0.011^{\mathrm{A}} \mathrm{a} \\
\end{array}$ & $\begin{array}{r}0.597 \\
\pm 0.004^{\mathrm{B}}{ }_{\mathrm{a}}\end{array}$ & $\begin{array}{r}0.742 \\
\pm 0.008^{\mathrm{C}} \\
\end{array}$ & $\begin{array}{c}0.663 \\
\pm 0.006^{\mathrm{D}} \\
\end{array}$ & $\begin{array}{c}0.657 \\
\pm 0.006^{\mathrm{D}} \\
\end{array}$ & $\begin{array}{c}0.859 \\
\pm 0.009^{\mathrm{E}} \\
\end{array}$ \\
\hline \multirow[t]{2}{*}{$\begin{array}{c}30 \text { days } \\
\mathrm{n}=5\end{array}$} & $\begin{array}{c}1.184 \\
\pm 0.012^{\mathrm{A}}\end{array}$ & $\begin{array}{r}0.639 \\
\pm 0.005^{\mathrm{B}}{ }_{\mathrm{b}}\end{array}$ & $\begin{array}{c}0.957 \\
\pm 0.010^{C}\end{array}$ & $\begin{array}{c}0.801 \\
\pm 0.007_{b}^{D}\end{array}$ & $\begin{array}{c}0.789 \\
\pm 0.007_{b}^{D}\end{array}$ & $\begin{array}{c}1.179 \\
\pm 0.005^{\mathrm{E}}{ }_{\mathrm{b}}\end{array}$ \\
\hline & \multicolumn{6}{|c|}{ FT4 (ng/dL) } \\
\hline $\begin{array}{c}15 \text { days } \\
n=5\end{array}$ & $\begin{array}{c}0.529 \\
\pm 0.003\end{array}$ & $\begin{array}{c}0.513 \\
\pm 0.003\end{array}$ & $\begin{array}{c}0.519 \\
\pm 0.003\end{array}$ & $\begin{array}{c}0.524 \\
\pm 0.003\end{array}$ & $\begin{array}{c}0.517 \\
\pm 0.003\end{array}$ & $\begin{array}{c}0.525 \\
\pm 0.003\end{array}$ \\
\hline $\begin{array}{c}30 \text { days } \\
n=5\end{array}$ & $\begin{array}{c}0.522 \\
\pm 0.003\end{array}$ & $\begin{array}{c}0.526 \\
\pm 0.003\end{array}$ & $\begin{array}{c}0.524 \\
\pm 0.003\end{array}$ & $\begin{array}{c}0.518 \\
\pm 0.003\end{array}$ & $\begin{array}{c}0.513 \\
\pm 0.003\end{array}$ & $\begin{array}{c}0.520 \\
\pm 0.003\end{array}$ \\
\hline
\end{tabular}

- A, B, C, D, E Means with a common superscript within a row are significantly different at $(\mathrm{P}<0.05)$.

- a, b Means with a common subscript within a column are significantly different at $(P<0.05)$. 
Hammam, et al.,

Table (4): Therapeutic role of ginseng, green tea or cinnamon and their mixture against hazard effects of $y$-radiation on the tissues liver and cardiac antioxidant (GSH content \& Gpx activity) and oxidative (TBARS level) status in rats (Mean \pm SE).

\begin{tabular}{|c|c|c|c|c|c|c|}
\hline \multirow[b]{2}{*}{ Interval } & Control & $\begin{array}{l}\text { Irradiated } \\
\text { recover }\end{array}$ & $\begin{array}{c}\text { Irradiated } \\
+ \\
\text { ginseng }\end{array}$ & $\begin{array}{c}\text { Irradiated }+ \\
\text { green tea }\end{array}$ & $\begin{array}{c}\text { Irradiated + } \\
\text { Cinnamon }\end{array}$ & $\begin{array}{l}\text { Irradiated + } \\
\quad \text { Mixture }\end{array}$ \\
\hline & \multicolumn{6}{|c|}{ Tissues liver GSH (mg/g tissue) content } \\
\hline $\begin{array}{c}15 \text { days } \\
n=5\end{array}$ & $\begin{array}{c}27.702 \\
\pm 0.187_{a}^{\mathrm{A}}\end{array}$ & $\begin{array}{r}16.429 \\
\pm 0.101^{\mathrm{B}}{ }_{\mathrm{a}}\end{array}$ & $\begin{array}{r}19.281 \\
\pm 0.132^{C}{ }_{a}\end{array}$ & $\begin{array}{r}17.839 \\
\pm 0.118^{\mathrm{D}}{ }_{\mathrm{a}}\end{array}$ & $\begin{array}{r}17.928 \\
\pm 0.117^{\mathrm{D}}\end{array}$ & $\begin{array}{r}22.026 \\
\pm 0.142^{\mathrm{E}}{ }_{\mathrm{a}}\end{array}$ \\
\hline $\begin{array}{c}30 \text { days } \\
\mathrm{n}=5\end{array}$ & $\begin{array}{c}27.593 \\
\pm 0.185^{\mathrm{A}} \mathrm{a}\end{array}$ & $\begin{array}{c}18.874 \\
\pm 0.124^{\mathrm{B}}{ }_{\mathrm{b}} \\
\end{array}$ & $\begin{array}{c}22.929 \\
\pm 0.129^{C} \\
\end{array}$ & $\begin{array}{c}19.984 \\
\pm 0.121_{b}^{\mathrm{D}} \\
\end{array}$ & $\begin{array}{r}19.979 \\
\pm 0.121^{\mathrm{D}} \mathrm{b} \\
\end{array}$ & $\begin{array}{c}25.114 \\
\pm 0.163^{\mathrm{E}}{ }_{\mathrm{b}} \\
\end{array}$ \\
\hline & \multicolumn{6}{|c|}{ Tissues liver Gpx $(\mu \mathrm{mol} / \mathrm{min} / \mathrm{g}$ tissue $)$ activity } \\
\hline $\begin{array}{c}15 \text { days } \\
n=5\end{array}$ & $\begin{array}{r}129.498 \\
\pm 1.325^{\mathrm{A}}\end{array}$ & $\begin{array}{r}85.638 \\
\pm 0.886^{\mathrm{B}}{ }_{\mathrm{a}} \\
\end{array}$ & $\begin{array}{r}95.494 \\
\pm 0.923 \mathrm{C}_{\mathrm{a}} \\
\end{array}$ & $\begin{array}{r}90.021 \\
\pm 0.904_{\mathrm{a}}^{\mathrm{D}} \\
\end{array}$ & $\begin{array}{r}89.997 \\
\pm 0.898^{\mathrm{D}} \mathrm{a}\end{array}$ & $\begin{array}{r}100.546 \\
\pm 1.117^{\mathrm{E}}\end{array}$ \\
\hline $\begin{array}{c}30 \text { days } \\
n=5\end{array}$ & $\begin{array}{l}129.504 \\
\pm 1.327^{\mathrm{A}} \mathrm{a}\end{array}$ & $\begin{array}{r}96.221 \\
\pm 0.947_{b}^{B} \\
\end{array}$ & $\begin{array}{r}107.402 \\
\pm 1.189^{\mathrm{C}} \\
\end{array}$ & $\begin{array}{r}100.558 \\
\pm 1.124{ }_{b}^{D}\end{array}$ & $\begin{array}{r}100.003 \\
\pm 1.109^{\mathrm{D}} \\
\end{array}$ & $\begin{array}{r}117.253 \\
\pm 1.265{ }_{b}\end{array}$ \\
\hline & \multicolumn{6}{|c|}{ Tissues liver TBARS (nmol/100 mg tissue) level } \\
\hline $\begin{array}{c}15 \text { days } \\
n=5\end{array}$ & $\begin{array}{c}1.8288^{\mathrm{A}} \\
\pm 0.018_{\mathrm{a}}\end{array}$ & $\begin{array}{c}4.006 \\
\pm 0.032^{\mathrm{B}} \mathrm{a} \\
\end{array}$ & $\begin{array}{c}3.018 \\
\pm 0.026^{\mathrm{C}} \mathrm{a}\end{array}$ & $\begin{array}{c}3.729 \\
\pm 0.028^{\mathrm{D}} \mathrm{a} \\
\end{array}$ & $\begin{array}{c}3.736 \\
\pm 0.028^{\mathrm{D}} \\
\end{array}$ & $\begin{array}{r}2.502 \\
\pm 0.022{ }^{\mathrm{E}}{ }_{\mathrm{a}}\end{array}$ \\
\hline $\begin{array}{c}30 \text { days } \\
n=5\end{array}$ & $\begin{array}{r}1.831 \\
\pm 0.019^{\mathrm{A}} \mathrm{a} \\
\end{array}$ & $\begin{array}{r}3.327 \\
\pm 0.027^{\mathrm{B}} \mathrm{b} \\
\end{array}$ & $\begin{array}{r}2.623{ }^{\mathrm{C}} \\
\pm 0.02 \mathrm{c}_{\mathrm{b}} \\
\end{array}$ & $\begin{array}{r}3.009 \\
\pm 0.025_{\mathrm{b}}^{\mathrm{D}} \\
\end{array}$ & $\begin{array}{r}3.018 \\
\pm 0.026^{\mathrm{D}} \\
\end{array}$ & $\begin{array}{r}1.838 \\
\pm 0.019^{\mathrm{A}} \mathrm{b} \\
\end{array}$ \\
\hline & \multicolumn{6}{|c|}{ Tissues Cardiac GSH (mg/g tissue) content } \\
\hline $\begin{array}{c}15 \text { days } \\
n=5\end{array}$ & $\begin{array}{c}14.727 \\
\pm 0.120^{\mathrm{A}} \\
\end{array}$ & $\begin{array}{r}9.762 \\
\pm 0.066^{\mathrm{B}}{ }_{\mathrm{a}} \\
\end{array}$ & $\begin{array}{r}12.008 \\
\pm 0.087^{\mathrm{C}} \mathrm{a} \\
\end{array}$ & $\begin{array}{r}11.329 \\
\pm 0.073^{\mathrm{D}}{ }_{\mathrm{a}} \\
\end{array}$ & $\begin{array}{r}11.308 \\
\pm 0.072^{\mathrm{D}} \mathrm{a} \\
\end{array}$ & $\begin{array}{r}12.879 \\
\pm 0.101^{\mathrm{E}} \\
\end{array}$ \\
\hline $\begin{array}{c}30 \text { days } \\
\mathrm{n}=5\end{array}$ & $\begin{array}{r}14.740 \\
\pm 0.123^{\mathrm{A}} \mathrm{a} \\
\end{array}$ & $\begin{array}{r}11.182 \\
\pm 0.074 \mathrm{~b} \\
\end{array}$ & $\begin{array}{r}13.116 \\
\pm 0.112{ }^{C} b \\
\end{array}$ & $\begin{array}{r}12.558 \\
\pm 0.093{ }_{b} \\
\end{array}$ & $\begin{array}{r}12.549 \\
\pm 0.092{ }_{b} \\
\end{array}$ & $\begin{array}{r}14.731 \\
\pm 0.125{ }^{\mathrm{A}} \\
\end{array}$ \\
\hline & \multicolumn{6}{|c|}{ Tissues cardiac Gpx ( $\mu \mathrm{mol} / \mathrm{min} / \mathrm{g}$ tissue $)$ activity } \\
\hline $\begin{array}{c}15 \text { days } \\
n=5\end{array}$ & $\begin{array}{c}72.659 \\
\pm 0.832^{\mathrm{A}}{ }_{\mathrm{a}}\end{array}$ & $\begin{array}{c}58.172 \\
\pm 0.597_{a}^{\mathrm{B}}\end{array}$ & $\begin{array}{c}64.853 \\
\pm 0.681^{\mathrm{C}} \mathrm{a}\end{array}$ & $\begin{array}{c}61.239 \\
\pm 0.632^{\mathrm{D}} \\
\end{array}$ & $\begin{array}{c}61.226 \\
\pm 0.628^{\mathrm{D}}\end{array}$ & $\begin{array}{c}67.551 \\
\pm 0.733^{\mathrm{E}}{ }_{\mathrm{a}}\end{array}$ \\
\hline $\begin{array}{c}30 \text { days } \\
n=5\end{array}$ & $\begin{array}{r}72.278 \\
\pm 0.824^{\mathrm{A}}{ }_{\mathrm{a}}\end{array}$ & $\begin{array}{r}62.352 \\
\pm 0.643_{\mathrm{b}}^{\mathrm{B}} \\
\end{array}$ & $\begin{array}{r}68.559 \\
\pm 0.762{ }^{C}{ }_{b} \\
\end{array}$ & $\begin{array}{r}64.749 \\
\pm 0.675_{\mathrm{b}}^{\mathrm{D}} \\
\end{array}$ & $\begin{array}{r}64.713 \\
\pm 0.669 \mathrm{D}_{\mathrm{b}} \\
\end{array}$ & $\begin{array}{r}72.472 \\
\pm 0.828 \mathrm{~A}_{\mathrm{b}}\end{array}$ \\
\hline & \multicolumn{6}{|c|}{ Tissues cardiac TBARS ( $\mathrm{nmol} / 100 \mathrm{mg}$ tissue) level } \\
\hline $\begin{array}{c}15 \text { days } \\
n=5\end{array}$ & $\begin{array}{c}1.118 \\
\pm 0.009^{\mathrm{A}}{ }_{\mathrm{a}} \\
\end{array}$ & $\begin{array}{r}2.419 \\
\pm 0.019^{\mathrm{B}} \mathrm{a} \\
\end{array}$ & $\begin{array}{r}1.854 \\
\pm 0.019^{\mathrm{C}}{ }_{\mathrm{a}} \\
\end{array}$ & $\begin{array}{c}2.009 \\
\pm 0.017^{\mathrm{D}} \\
\end{array}$ & $\begin{array}{r}2.013 \\
\pm 0.017_{a}^{\mathrm{D}} \\
\end{array}$ & $\begin{array}{c}1.527 \\
\pm 0.011{ }^{\mathrm{E}} \\
\end{array}$ \\
\hline $\begin{array}{c}30 \text { days } \\
n=5\end{array}$ & $\begin{aligned} & 1.120 \\
\pm & 0.009^{\mathrm{A}}\end{aligned}$ & $\begin{array}{c}2.003 \\
\pm 0.017^{B} \\
\end{array}$ & $\begin{array}{r}1.362 \\
\pm 0.012^{C} b\end{array}$ & $\begin{array}{c}1.528 \\
\pm 0.015^{\mathrm{D}}\end{array}$ & $\begin{array}{r}1.536 \\
\pm 0.015^{\mathrm{D}} \\
\end{array}$ & $\begin{array}{r}1.212 \\
\pm 0.009^{A}\end{array}$ \\
\hline
\end{tabular}

- A, B, C, D, E Means with a common superscript within a row are significantly different at $(\mathrm{P}<0.05)$.

- a, b Means with a common subscript within a column are significantly different at $(P<0.05)$.

\section{CONCLUSION}

So, it is possible to conclude that the mixture of ginseng, green tea and cinnamon can ameliorate the harmful effects of exposure to $\mathrm{Y}$-radiation in rats which prevent the $y$-radiation induced oxidative liver damage as well as inflammatory stress in liver by alleviating lipid peroxidation through free radical scavenging or by enhancing the synthesis of antioxidants and improves glutathione redox system which then detoxify free radicals. Also, this study can practically help to encourage the clinical use of this mixture as a treatment for exposure to 
$Y$-radiation. However, we believe that the mixture of ginseng, green tea and cinnamon should be further evaluated for their radioprotective potentials in a clinical setting.

\section{REFERENCES}

Abd El-Megid, M.H.M. (2014). Biochemical studies on the addition of some natural products on lipid profile in rats exposed to gamma ray. Egyptian Journal of Radiation Sciences and Applications; 27:313-333.

Adams, M.J., P.H. Hardenbergh, L.S. Constine and S.E. Lipshultz (2003). Radiation-associated cardiovascular disease. Critical reviews in oncology/hematology; 45(1):55-75.

Akbarzadeh, T., R. Sabourian, M. Saeedi, H. Rezaeizadeh and A. Khanavi (2015). Liver tonics: review of plants used in Iranian traditional medicine. Asian Pac. J. Trop. Biomed.; 5(3):170-181.

Andratschke, N., J. Maurer, M. Molls and K.R. Trott (2011). Late radiation-induced heart disease after radiotherapy. Clinical importance radiobiological mechanisms and strategies of prevention, Radiother. Oncol.; 100(2):160-166.

Anees, L.M., R.M. Ibrahim and E.M. Kamal El-Dein (2014). Protective effect of Panax Ginseng against radiation induced oxidative stress on liver tissue of male albino rats. AJPCT; 2(10):1141-1158.

Bhosle, S.M., N.G. Huilgol and K.P. Mishra (2005). Enhancement of radiationinduced oxidative stress and cytotoxicity in tumor cells by ellagic acid. Clin. Chim. Acta; 359:89-100.

Chaput, J.P., H. Arguin, C. Gagnon and A. Tremblay (2008). Increase in depression symptoms with weight loss: association with glucose homeostasis and thyroid function. Appl. Physiol. Nutr. Metab.; 33(1):86-92.

Choi, J.S., H. Young, S. Park and S. Kim (2016). Radioprotective effect of epigallocatechin-3-eallate on salivary gland dysfunction after radioiodine ablation in a murine model. Clinical and
Experimental Otorhinolaryngology; 51:974-981.

Deniz-Uluısık, D. and E. Keskin (2016). Hepatoprotective effects of ginseng in rats fed cholesterol rich diet. Acta Scientiae Veterinariae; 44:1346-1352.

El-Missiry, M.A., T.A. Fayed, M.R. El-Sawy and A.A. El-Sayed (2007). Ameliorative effect of melatonin against gammairradiation induced oxidative stress and tissue injury. Ecotoxicology and environment safety; 66:278-286.

Ezz, M.K. (2011). The Ameliorative effect of Echinacea purpurea against gamma radiation induced oxidative stress and immune responses in male rats. Australian Journal of Basic and Applied Sciences; 5(10):506-512.

Gupta, J., Y.H. Siddique, T. Beg, G. Ara and M. Afzal (2009). Protective role of green tea extract against genotoxic damage induced by anabolic steroids in cultured human lymphocytes, Biology and Medicine; 1(2):87-99.

Heibashy, M.I.A. and M.N.M. Sharoud (2008). Attenuation of the disruptive effects induced by gamma irradiation in rats using ozonated water and/or taurine. Isotope \& Rad. Res.; 40, 4 (suppl. 2):1527-1541.

Heibashy, M.I.A., A.M. El-Nahla, T.A. Ismail and A. A. H. Shallaby (2013a). Green tea ameliorates adrimycin toxicity in rats. Lucrari Stiintifice, Seria Medicina Veterinara; 56(1-2): 165-179.

Heibashy, M.I.A., F.A. El-Negamy, M.I. Shahin and N.A. Kelada (2011). Obesity and subsequent cardiovascular events in rats and the potential benefit of some antioxidants supplementation. Isotope \& Rad. Res.; 51, 2 (suppl. 2):549-557.

Heibashy, M.I.A., G.M.A. Mazen and M.A. Ibrahim (2014). Efficacy and safety of some medical herbs on gastric ulcer induced by aspirin in rats. J. Pharmacy and Biological Sciences; 9(3):19-27.

Heibashy, M.I.A., G.M.A. Mazen and M.I. Shahin (2013b). Metabolic Changes and Hormonal Disturbances in Polycystic 
Ovarian Syndrome Rats and the Amelioration Effects of Metformin and/or Cinnamon Extraction. J. Am. Sci.; 9(12):54-62.

Heibashy, M.I.A., N.Z. Zaki and W.A.M. ElNahrawy (2010). Alterations in insulin, leptin, orexin- $A$ and neuropeptide- $Y$ levels in the high-fat diet fed rats. Australian J. Basic and Applied Sciences, 4(6):1473-1481.

Hewala, T.I. (2015). The radioprotective effect of green tea extract on gammairradiated mice. Radiation \& Isotopes; 35(2):154-161.

Jagetia, G.C. (2007). Radioprotective potential of plants and herbs against the effects of ionizing radiation. J Clin Biochem Nutr.; 40:74-81.

Kiang, J.G., J.A. Smith and N.G. Agravante (2009). Geldanamycin analog 17-DMAG inhibits iNOS and caspases in gamma irradiated human $\mathrm{T}$ cells. Radiat. Res.; 172:321-330.

Lee, K.H., Y. Han, S.J. Son, M. Akhalaia, A. Platonov and H.J. Son (2016). Modulation of radiation-induced disturbances of antioxidant defense systems by ginsan. Evid. based Complement Alternat. Med.; 11:5293652947.

Liu, Y., D. Xu, X. Wang, X. Zhang, D. Dai, S. Chen and M. Zhang (2009). Influence of squalene feeding on plasma leptin, testosterone \& blood pressure in rats. Indian J. Med. Res.; 129(2): 150-153.

Mansour, H.H. (2013). Protective effect of ginseng against gamma-radiationinduced oxtative stress and endothelial dysfunction in rats. EXCLI Journal; 12:766-777.

Said, S.M. and K.H. Husein (2009). Hepatoprotective effect of Cinnamon extracts against carbon tetrachloride induced oxidative stress and liver injury in rats. Biol. Res.; 42:93-98.

Sano, M., M. Tabata, M. Suzuki, M. Degawa, T. Miyase and MaedaYamamoto, M. (2001). Simultaneous determination of twelve tea catechins by highperformance liquid chromatography with electrochemical detection. Analyst; 126:816-820.
Shalaby, M.A. and A.A. Hamouda (2013). Antiobesity, antioxidant and antidiabetic activities of red ginseng plant extract in obese diabetic rats. J. Intercult. Ethnopharmacol.; 2(3):165-172

Shalaby, M.A. and Y. Saifan (2014). Some pharmacological effects of cinnamon and ginger herbs in obese diabetic rats. J. Intercult. Ethnopharmacol.; 3(4): 144149

Sharma, J., R. Sharma and A. Mathur (2013). Protection of mouse liver from gamma exposure: Int. J. Pharm. Bio. Sci.; 4(1-P): 1011-1026.

Singh, V.K. and V.S. Yadav (2005). Role of cytokines and growth factors in radioprotection. Exp. Mol. Pathol.; 78:156-169.

Snedecor, G.W. and W.G. Cochran (1982). "Statistical Methods" $7^{\text {th }}$ ed. Two State University press, Ames lowa, U.S.A.

Swerdlow, A.J., C.D. Higgins, P. Smith, D. Cunningham, B.W. Hancock and A. Horwich (2007). Myocardial infarction mortality risk after treatment for Hodgkin disease: a collaborative British cohort study. J. Natl. Cancer Inst.; 99(3):206214.

Uma-devi, P., A. Ganasoundari, B. Vrinda, K.K. Srinivasan and M.K. Unnikrishnan (2013). Radiation protection by the ocimum. Int. J. Pharm. Bio. Sci.; 4(1):1011-1026.

Vangalapati, M., S.N. Sree, V. Prakash, D. Surya and S. Avanigadda (2012). A Review on pharmacological activities and clinical effects of cinnamon species. Research Journal of Pharmaceutical, Biological and Chemical Sciences; 3(1):653-663.

Verma, P., S. Jahan, T.S. Kim and P.K. Goyal (2011). Management of radiation injuries by Panax ginseng extract. J. Ginseng Res.; 35(3):261-271.

Vinson, J.A. (2000). Black and green tea and heart disease: a review. Biofactors; 13:127-132. 


\section{دراسات كيميائية على بعض الأعشاب الطبية ضد الإشعاع الجامى المحدث لإختلاف بيوكيمائية فى وظائف الكبا والقلب للجرذان}

مصطقى عبدالله محمد همام(1) ، محمد إسلام حبيشى(2) ، فؤاد مطاوع الشونى(1) ،

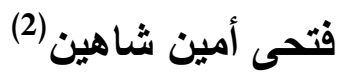

$$
\text { (1) - كلية الزراعة - جامعة المنوفية }
$$

(2) مركز البحوث النووية هيئة الطاقة الذرية الزية

الملخص العربي

• العذف من هذه الدراسة هو تقبيم قدرة مستخلصات نباتات الجنسنج والثاي الأخضر والقرفة لتحسين الأضطرابات التي

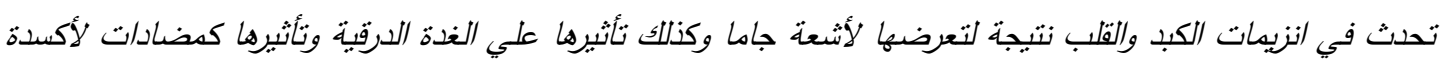

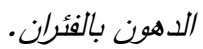

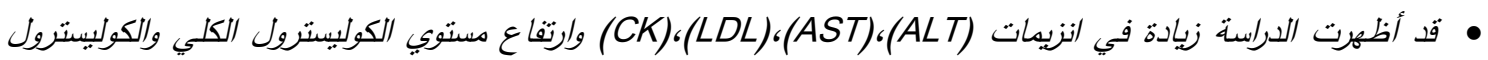

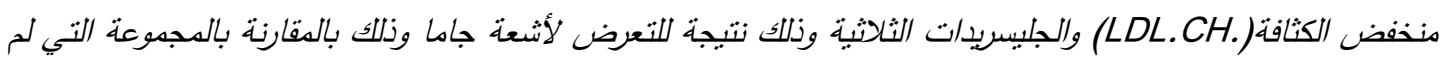

$$
\text { تتعرض للأشعاع. }
$$

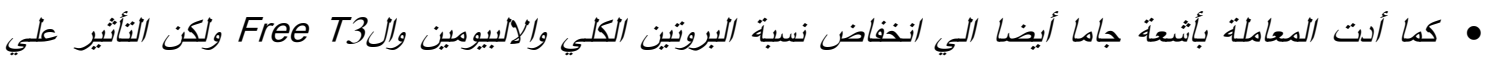

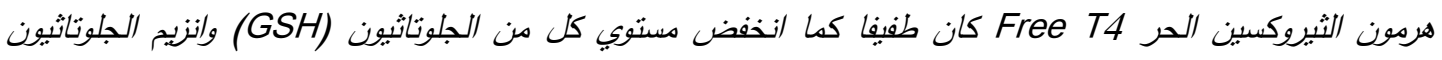

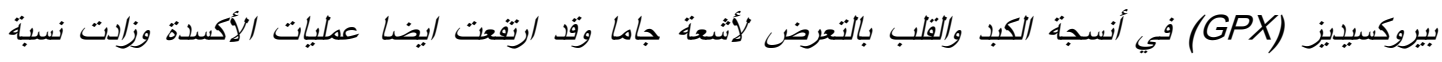
Thiobarbituric acid (TBARS)

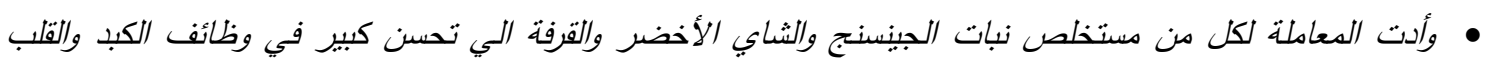
وانخفض مستوي الدهون في الدم وتحسن مستوي هرمونات الغدة الدرقية ومقاومة الاجهاد الثأكسدي.

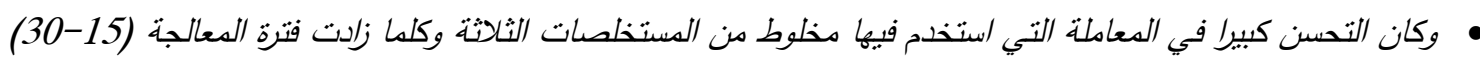

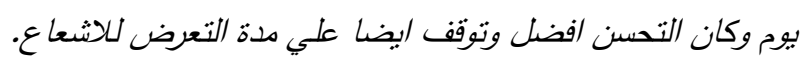

• واستتنج من هذه الدراسة أنه بيكن استخدام الدستخلصات السابقة كوسيلة للوقاية من أخطار التعرض لأشعة جاما. 